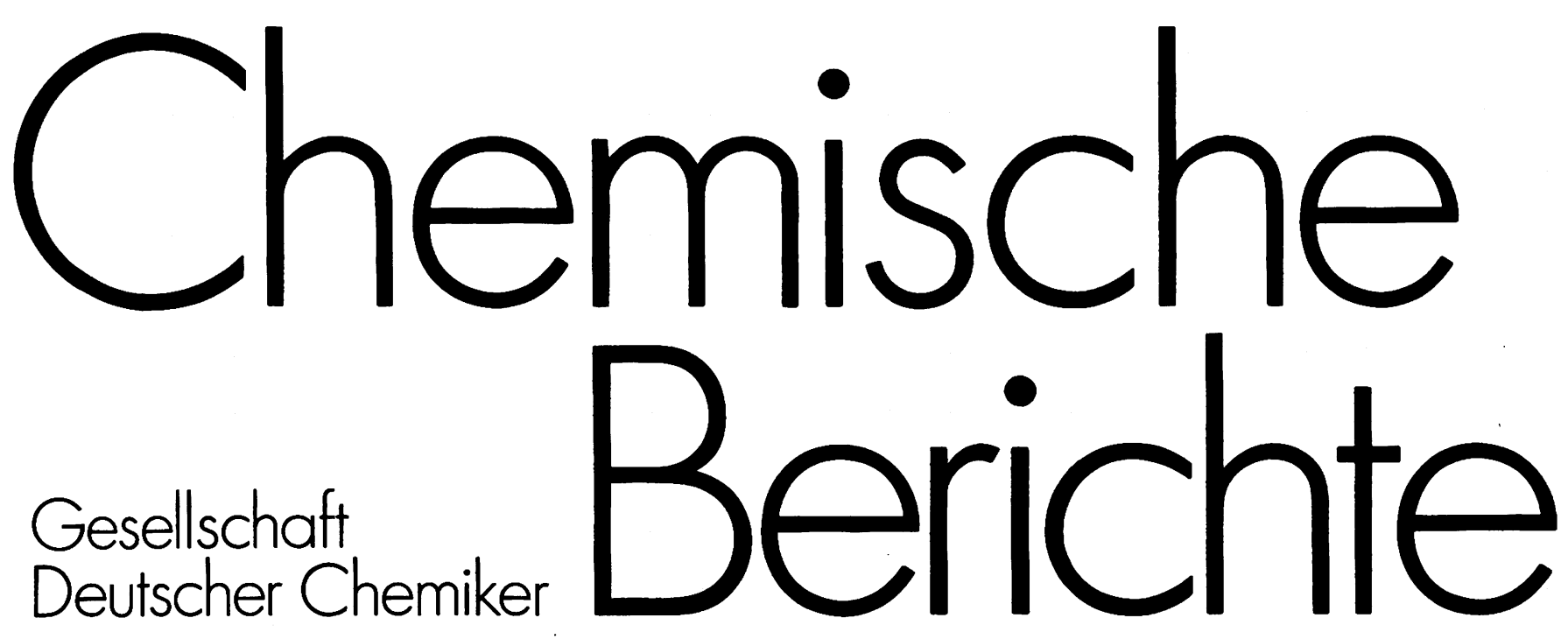

Founded 1868

March 1994 - Volume 127 - Issue 3 - Pages 447-586

$\begin{array}{lll}\text { Editorial Board: } & \text { Wolfgang Beck } & \text { Martin Jansen } \\ & \text { Rolf Gleiter } & \text { Klaus Müllen } \\ & \text { Klaus Hafner } & \text { Heinrich Nöth } \\ & \text { Henning Hopf } & \text { Werner Schroth }\end{array}$

$\begin{array}{llll}\text { Managing Editor: } & \text { Robert Temme } & \text { Administration: } & \text { Hannelore Holm } \\ \text { Associate Editors: } & \text { Udo Eberhardt } & \text { Production: } & \text { Olga Olivecká }\end{array}$

Editorial Office: Chemische Berichte

P.O. Box 101161

D-69451 Weinheim

Federal Republic of Germany

Telephone (internat.) +496201 606-255

Telefax (internat.) $\quad+496201606-328$ $\begin{array}{ll}\text { Administration: } & \text { Hannelore Holm } \\ \text { Production: } & \text { Olga Olivecká }\end{array}$

Helmut Schwarz

Werner Tochtermann

Heinrich Vahrenkamp 
Boese, R., Haas*, A., Lieb, M., Roeske, U.

Tris(perfluororganochalkogenyl)methyl-Verbindungen: Synthesen, Strukturen und Eigenschaften

Tris(perfluoroorganochalkogenyl)methyl Compounds: Synthesis, Structures, and Properties

$$
\begin{gathered}
\left(\mathrm{CF}_{3} \mathrm{~S}\right)_{2} \mathrm{CHC}\left(\mathrm{OC}_{2} \mathrm{H}_{5}\right)_{3} \stackrel{\mathrm{NaH} / \mathrm{CF}_{3} \mathrm{ECl}}{\longrightarrow}\left(\mathrm{CF}_{3} \mathrm{~S}_{2}\left(\mathrm{CF}_{3} \mathrm{E}\right) \mathrm{CC}(\mathrm{O}) \mathrm{OC}_{2} \mathrm{H}_{5}\right. \\
\stackrel{1}{\longrightarrow}\left(\mathrm{CF}_{3} \mathrm{~S}\right)_{2}\left(\mathrm{CF}_{3} \mathrm{E}\right) \mathrm{CC}(\mathrm{O}) \mathrm{C}_{2} \mathrm{H}_{5} \stackrel{\mathrm{H}_{2} \mathrm{SO}_{4}}{\longrightarrow}\left(\mathrm{CF}_{3} \mathrm{~S}\right)_{2}\left(\mathrm{CF}_{3} \mathrm{E}\right) \mathrm{CCN} \\
\mathbf{2}
\end{gathered}
$$

Brychcy, K., Dräger, K., Jens, K.-J., Tilset, M., Behrens*, U.

Komplexe mit makrocyclischen Liganden, I. - Zweikernige Kupfer(II)-Komplexe mit vollständig $\pi$-konjugiertem Makrocyclus vom Schiff-Basen-Typ: Synthesen, Strukturen, elektro- und magnetochemische Eigenschaften

Complexes with Macrocyclic Ligands, I. - Dinuclear Copper(II) Complexes with a Totally $\pi$-Conjugated Macrocycle of Schiff Base Type: Syntheses, Structures, Electro-, and Magnetochemical Properties

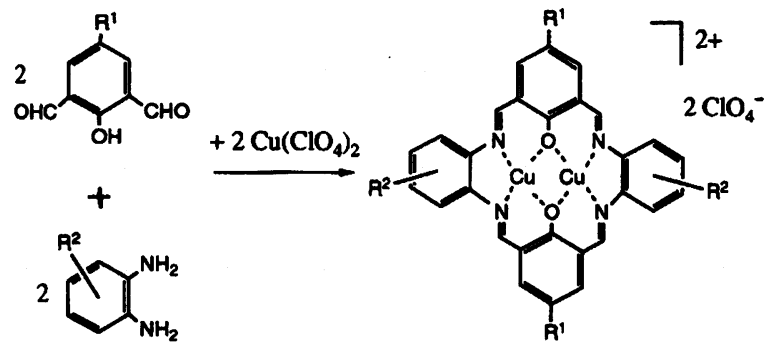

$\mathbf{R}^{1}=$ tert - Butyl; Perfluorisopropyl $\mathbf{R}^{2}=\mathbf{H} ; \mathbf{F}$
Drieß*, M., Pritzkow, $\mathrm{H}$.

(2,4,6-i $\left.\mathrm{Pr}_{3} \mathrm{C}_{6} \mathrm{H}_{2}\right)(t \mathrm{Bu}) \mathrm{Si}\left(\mathrm{AsH}_{2}\right)_{2}$ : Das erste Diarsanylsilan und seine Umwandlung in ein 1,3-Diarsa-2-sila-4 germacyclobutan und in ein 1,3-Diarsa-2-sila-4-germabicyclo[1.1.0]butan-Derivat

$\left(2,4,6-i \mathrm{Pr}_{3} \mathrm{C}_{6} \mathrm{H}_{2}\right)(t \mathrm{Bu}) \mathrm{Si}\left(\mathrm{AsH}_{2}\right)_{2}$ : The First Diarsanylsilane and Its Transformation into a 1,3-Diarsa-2-sila-4germacyclobutane and a 1,3-Diarsa-2-sila-4-germabicyclo[1.1.0]butane Derivate

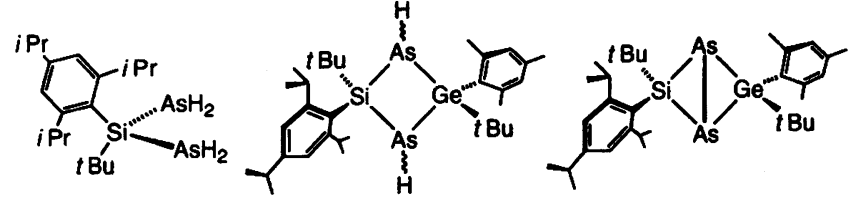

A

B
Heßler, A., Fischer, J., Kucken, S., Stelzer*, 0. Synthese und Koordinationschemie hemilabiler P,NHybridliganden mit terminalen 2-Pyridyl-Donorgruppierungen

Synthesis and Coordination Chemistry of Hemilabile P,N-Hybride Ligands with Terminal 2-Pyridyl Donor Groups<smiles></smiles>

18,19

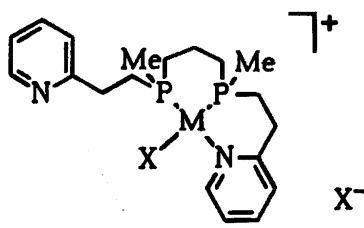

18,19 
Pluta, C., Pörschke*, K.-R., Gabor, B., Mynott, R.

\{Bis[bis(trimethylsilyl)methyl]stannio(II)\} bis $\left(\eta^{2}-\right.$ ethen)nickel( 0 ) und verwandte Verbindungen, Teil II $\left\{\right.$ Bis[bis(trimethylsilyl)methyl]stannio(II)\} bis( $\eta^{2}$ ethene)nickel( 0 ) and Related Compounds, Part II
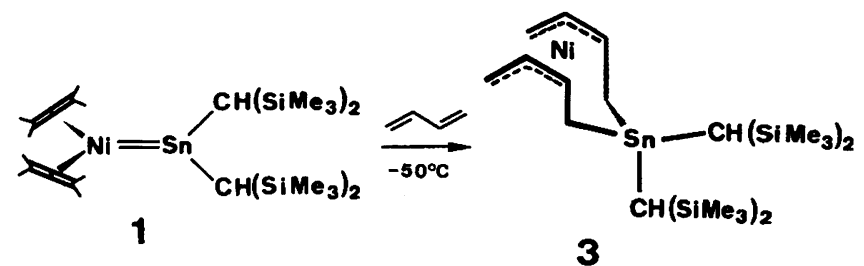

Janssen, B. C., Asam, A., Huttner*, G., Sernau, V., Zsolnai, L.

Funktionalisierte Tripod-Liganden: Synthese und Koordination von Tris[(diphenylphosphanyl)methyl]methan

Functionalized Tripod Ligands: Synthesis and Coordination of 1,1,1-Tris[(diphenylphosphanyl)methyl]me-

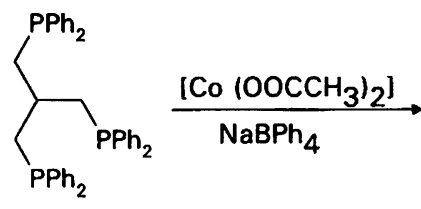

4<smiles>CC[PbH2]</smiles>
thane

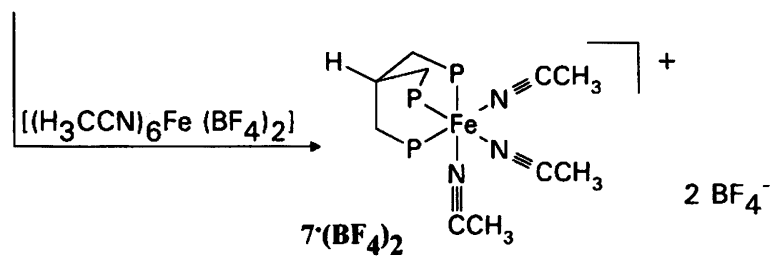

Teil B: Organische Chemie / Part B: Organic Chemistry

Rademacher*, P., Wiesmann, R. F.

Transanulare Wechselwirkungen in difunktionellen mittleren Ringen, 4. - Spektroskopische und theoretische Untersuchungen an bicyclischen Boraalkenen Transanular Interactions in Difunctional Medium Rings, 4. - Spectroscopic and Theoretical Investigations on Bicyclic Boraaikenes

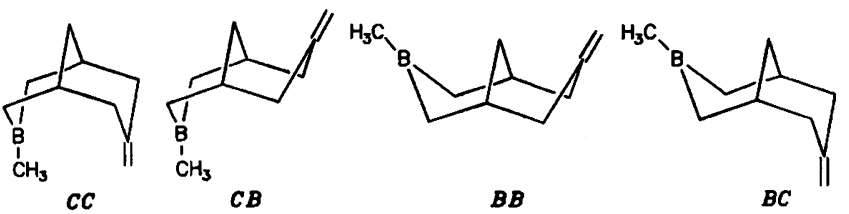

cc

$C B$

$B B$

519 Huang*, Z.-T., Wang, G.-Q.

Studie an Calixarenen, V. - Friedel-Crafts-Reaktion mit Calixarenen

Study of Calixarenes, V. - Friedel-Crafts Reaction of Calixarenes
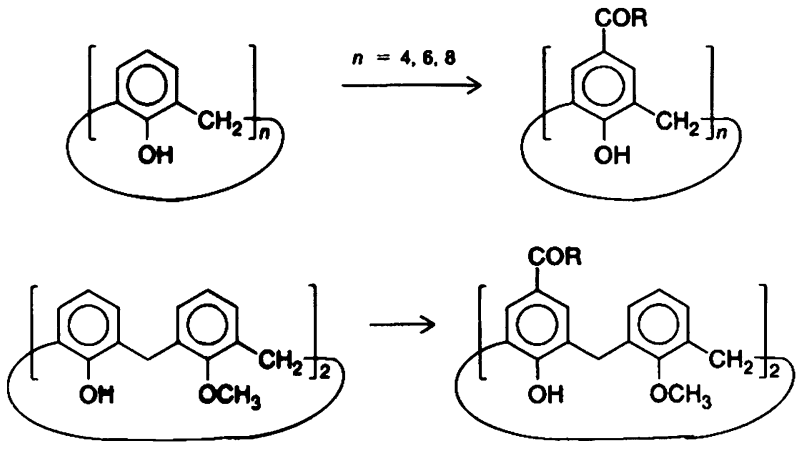
Mayr*, H., Gonzalez, J. L., Lüdtke, K.

Vergleich der Nucleophilie von Alkinen und Alkenen. Quantitative Bestimmung der Nucleophilie von Alkinen gegenüber Carbenium-Ionen

Comparison of the Nucleophilicities of Alkynes and Alkenes. Quantitative Determination of the Nucleophilicities of Alkynes toward Carbenium Ions
Second-Order-Rate-Constants toward $\left(p-\mathrm{MeC}_{6} \mathrm{H}_{4}\right)_{2} \mathrm{CH}^{+}$

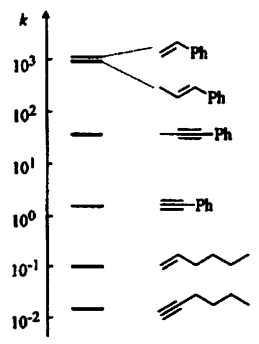

Reimann-Andersen, S., Pritzkow, H., Sundermeyer*, W.

Halogen-Kohlenstoff-Schwefel-Verbindungen: Zur Chemie von 1,1,1,4,4,4-Hexafluor-2-buten-2,3-bissulfenylchlorid

Halogen-Carbon-Sulfur Compounds: Syntheses with 1,1,1,4,4,4-Hexafluoro-2-butene-2,3-bissulfenyl Chloride

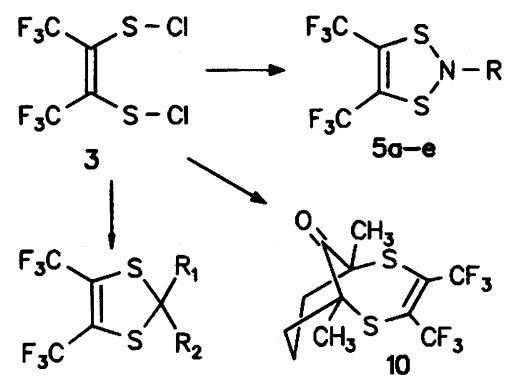

\section{$541 \quad$ Wang, Q., Al-Talib, M., Jochims*, J. C.}

Über die Reaktion von 1-Aza-2-azoniaallen-Salzen mit Acetylenen

On the Reaction of 1-Aza-2-azoniaallene Salts with Acetylenes

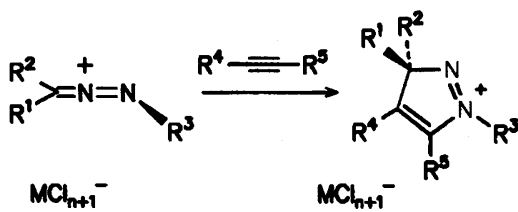<smiles></smiles>

$\mathrm{MCl}_{n+1}^{-}$

\section{Weinges*, K., Reichert, H., Braun, R.}

Radikalische Cyclisierung von Dienen, VIII. - Über die regioselektive Herstellung von ungesättigten Cyclopenta[b]furan-2-onen aus $(S)-(+)$-Carvon - Bausteine zur Synthese von enantiomerenreinen Triquinanen

Radical-Type Cyclization of Dienes, VIII. - On the Regioselective Synthesis of Unsaturated Cyclopenta[b]furan-2-ones from $(S)-(+)$-Carvone - Building Blocks for the Synthesis of Enantiomerically Pure Triquinanes

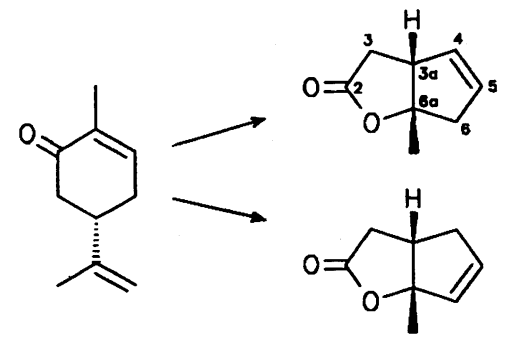

Blocher, A., Zeller*, K.-P.

Photolyse von Naphth[2,3- $d]$-1,2,3-oxadiazol - Ein Beitrag zum Oxiren-Problem

Photolysis of Naphth[2,3- $d$ ]-1,2,3-oxadiazole - A Contribution to the Oxirene Problem

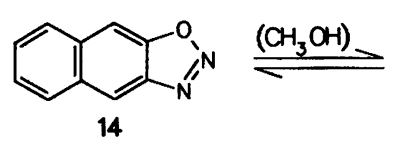<smiles>O=C1C=c2ccccc2=CC1=[18O]</smiles>

15<smiles>c1ccc2cc3c(cc2c1)O3</smiles>
$\mathrm{CH}_{3} \mathrm{OH} \mid-\mathrm{N}_{2}$

16<smiles>CC(=O)C1=Cc2ccccc2C1</smiles> 
Schaffer, F., Beckhaus, H.-D., Rieger, H.-J., Rüchardt*, $\mathrm{C}$.

Bimolekulare Bildung von Radikalen durch H-Transfer, 6. - Unkatalysierte Transfer-Hydrierung eines Benzhydrylfluorids durch 9,10-Dihydroanthracen

Bimolecular Formation of Radicals by $\mathbf{H}$-Transfer, 6 . - Uncatalyzed Transfer Hydrogenation of a Benzhydryl Fluoride by 9,10-Dihydroanthracene<smiles></smiles>

$\frac{330^{\circ} \mathrm{C}-375^{\circ} \mathrm{C}}{1-(\text { trimethyl- }}$ silyloxy)cyclohexene

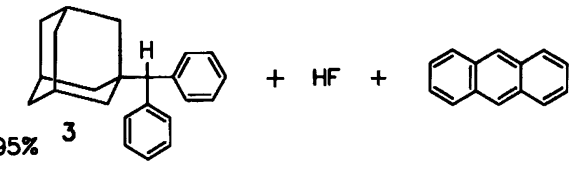

\section{Gautschi, M., Schweizer, W. B., Seebach*, D.}

In 2- und 3-Stellung verzweigte, enantiomerenreine 4,4,4-Trifluor-3-hydroxy-buttersäure-Derivate aus 6Trifluormethyl-1,3-dioxan- und -dioxin-4-onen

Preparation of Enantiomerically Pure 4,4,4-Trifluoro3-hydroxy-butanoic Acid Derivatives, Branched in the 2- or 3-Position, from 6-Trifluoromethyl-1,3-dioxanand -dioxin-4-ones<smiles>CC(C)(C)C1OC(=O)C[C@@H](C(F)(F)F)O1</smiles><smiles>CC(C)(C)C1OC(=O)C=C(C(F)(F)F)O1</smiles><smiles>CC(C)(C)C(Br)C(=O)O</smiles>

(or enantiomers)

\section{Notiz / Note}

581

Irngartinger*, H., Köhler, C.-M., Huber-Patz, U., Krätschmer, W.

Funktionalisierung von $\mathrm{C}_{60}$ mit Nitriloxiden zu 4,5Dihydroisoxazolen und deren Strukturbestimmung

Functionalisation of $\mathrm{C}_{60}$ with Nitrile Oxides to 4,5Dihydroisoxazoles and their Structure Determination

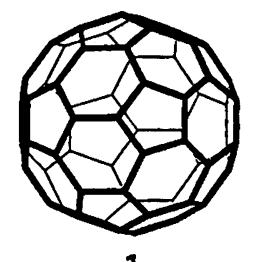

1

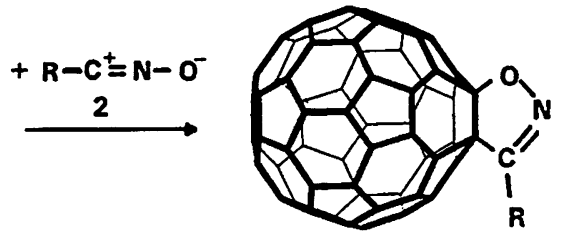

3

\section{Berichtigung / Correction}

\section{Hoffmann, R., Brückner*, R.}

Ein neuartiger Einstieg in Wittig-Umlagerungen Eine stereoselektive [1,2]-Wittig-Umlagerung mit Konfigurationsumkehr am Carbanion-Zentrum

A Novel Entry into Wittig Rearrangements - A Stereoselective [1,2]-Wittig Rearrangement with Inversion of Configuration at the Carbanion Center 


\title{
Comparison of the Nucleophilicities of Alkynes and Alkenes. Quantitative Determination of the Nucleophilicities of Alkynes toward Carbenium Ions
}

\author{
Herbert Mayr*a, Jose L. Gonzalez ${ }^{a}$, and Kerstin Lüdtke \\ Institut für Organische Chemie der Technischen Hochschule Darmstadt ${ }^{\mathrm{a}}$, \\ Petersenstraße 22, 64287 Darmstadt, Germany \\ Institut für Chemie der Medizinischen Universität zu Lübeck ${ }^{\mathbf{b}}$, \\ Ratzeburger Allee 160, 23538 Lübeck, Germany \\ Received August 4, 1993
}

Key Words: Alkynes / Alkenes / Nucleophilicity / Carbenium ions / Vinyl cations / Kinetics

Relative reactivities of alkenes and alkynes toward diarylmethyl cations have been determined by direct rate measurements and by competition experiments in dichloromethane. At $-70^{\circ} \mathrm{C}$ alkynes are found to be one to two orders of magnitude less reactive than analogously substituted alkenes (e.g. phenylacetylene/styrene), but the reactivity difference reduces strongly as the temperature is raised. The stereochemistry of the vinyl chlorides produced by addition of benzhydryl chlorides to alkynes is characterized.
Alkynes react much more slowly with halogens than alkenes and are, therefore, often considered to be weak nucleophiles $^{[1]}$. On the other hand, protons attack alkynes and structurally related alkenes with comparable rates ${ }^{[2,3]}$, and carbenium ions have also been reported to reveal similar reactivity toward phenylacetylene and styrene ${ }^{[4]}$. An explanation for these phenomena has been presented by Modena et al. ${ }^{[5]}$ : Electrophiles with strong bridging tendency react faster with alkenes than with alkynes, while electrophiles with weak bridging tendency show similar reactivities toward alkenes and alkynes.

We have recently studied the kinetics of the reactions of diarylmethyl cations with alkenes ${ }^{[6-10]}$, allyl-element compounds ${ }^{[11,12]}$, enol ethers ${ }^{[13]}$, and arenes ${ }^{[14]}$. On the basis of these data we have set up a reactivity scale including different types of $\pi$ nucleophiles ${ }^{[14]}$.

In order to add alkynes to this scale, we have measured the rate of the reaction of the 4-methoxybenzhydryl cation with phenylacetylene in $\mathrm{CH}_{2} \mathrm{Cl}_{2}$ at $-70^{\circ} \mathrm{C}$. Surprisingly, a rate constant $\left(k_{2}=0.0721 \mathrm{~mol}^{-1} \mathrm{~s}^{-1}\right) 150$ times smaller than that of styrene ${ }^{[8]}$ has been found, while Modena's competition experiments with $\mathrm{Ph}_{2} \mathrm{CHCl} / \mathrm{ZnCl}_{2}$ in $\mathrm{CH}_{2} \mathrm{Cl}_{2}$ indicate comparable reactivities for structurally analogous alkenes and alkynes $\left(k_{\text {styrene }} / k_{\text {phenylacetylene }}=3.8\right)^{[4]}$.

We have, therefore, reinvestigated the problem of relative reactivities of alkenes and alkynes, and we will show that the discrepancy between Modena's competition experiments and our direct rate measurements is predominantly due to the different temperature used for the two types of experiments.

\section{Reaction Products}

As previously described by Modena and coworkers ${ }^{[15]}$, the $\mathrm{ZnCl}_{2}$-catalyzed reaction of chlorodiphenylmethane (1a) with phenylacetylene (2) gives a mixture of $(E)-3 a$ and $(Z)-3 a$, the ratio of which is controlled by the different steric shielding of the two sites of $3^{+}$(Scheme 1). A similar behavior has now been found for the two benzhydryl chlorides $1 \mathbf{b}$ and $1 \mathrm{c}$.

While 1-phenyl-1-propyne (4) and $\mathrm{Tol}_{2} \mathrm{CHCl}(1 \mathrm{~b})$ react with predominant formation of the $(E)$-isomer of $5 b^{[4]}$, the analogous reaction with 1-hexyne (6) gives a $1: 1$ mixture of the two stereoisomeric adducts $\mathbf{7 b}$, possibly due to an activationless collapse of the intermediate $\alpha$-alkyl-substituted vinyl cation with the negative counterion (Scheme 2).

Compounds 8-10, the products of the addition of diarylchloromethanes to styrene, trans-1-phenyl-1-propene, and 2-chloropropene, which are needed as reference compounds for the evaluation of the competition experiments, have been synthesized according to literature procedures $^{[16,17]}$.

\section{Determination of Absolute Rates}

Spectrophotometry has been the method of choice in previous kinetic investigations of the reactions of diarylmethyl cations with $\pi$ nucleophiles, since the solutions of the diarylmethyl cations completely fade upon addition of the CC double bond-containing nucleophiles ${ }^{[7,12]}$. When alkynes are added to the diarylcarbenium ion solutions, only a change of color is observed, however, and the absorptions at $\lambda_{\max }$ of the carbenium ions do not usually disappear completely during the reactions. 
Scheme 1<smiles>[R]c1ccc(C(Cl)c2ccc([R])cc2)cc1</smiles><smiles>[R]c1ccc([CH][C+]([CH2+])c2ccc([R])cc2)cc1</smiles><smiles>CC#Cc1ccccc1</smiles>

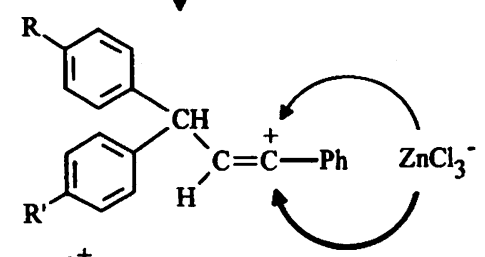

$3^{+}$<smiles>CCCC</smiles><smiles>[R]c1ccc(C(/C=C(/Cl)c2ccccc2)c2ccc([R])cc2)cc1</smiles>

(E)-3<smiles>[R]c1ccc(/C(Cl)=C/C(c2ccccc2)c2ccc([R])cc2)cc1</smiles>

(Z)-3

\begin{tabular}{l|llll}
\hline $\mathbf{R}, \mathbf{R}^{\prime}$ & 1,3 & & & \\
\hline H, H & a & 9 & $:$ & 1 \\
Me, Me & b & 7 & $:$ & 1 \\
OMe, H & c & 8 & $:$ & 1 \\
\hline
\end{tabular}

Scheme 2<smiles>CC#C[C@H](CCCCCCCC)C(C)=C(C)c1ccccc1</smiles>

4

$(E, Z)-5 b$

$80 \%(E),<10 \%(Z)$

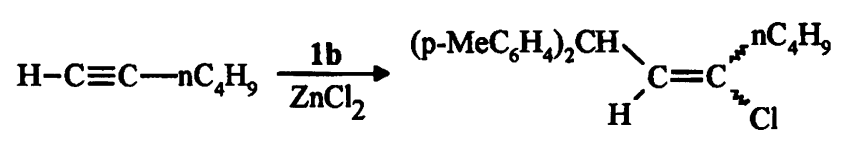

6
$(E, Z)-7 b$

(E) $:(\mathrm{Z})=1: 1$
$\mathrm{Ar}_{2} \mathrm{CH}-\mathrm{CH}_{2}-\mathrm{CH}-\mathrm{Ph}$

$\begin{array}{ll}\mathrm{Ar}=\mathrm{Ph}: & \mathbf{8 a} \\ \mathrm{Ar}=p-\mathrm{Me}-\mathrm{C}_{6} \mathrm{H}_{\mathbf{4}}: & \mathbf{8 b}\end{array}$

$\left(p-\mathrm{Me}-\mathrm{C}_{6} \mathrm{H}_{4}\right)_{2} \mathrm{CH}-\mathrm{CH}_{2}-\mathrm{CCl}_{2}-\mathrm{CH}_{3}$

$10 \mathrm{~b}$

Table 1. Rate constants for the reactions of diarylmethyl cations with alkynes in $\mathrm{CH}_{2} \mathrm{Cl}_{2}$ at $-70^{\circ} \mathrm{C}$

\begin{tabular}{lllll}
\hline $\mathrm{Ar}_{2} \mathrm{CH}^{+}$ & Alkyne & & $\mathrm{MCl}_{n}$ & $k_{2} / \mathrm{mol}^{-1} \mathrm{~s}^{-1}$ \\
\hline $\mathbf{1 \mathbf { a } ^ { + }}$ & $\mathrm{Ph}-\mathrm{C} \equiv \mathrm{CH}$ & $(2)$ & $\mathrm{TiCl}_{4}$ & $3.9 \times 10^{2}$ \\
$\mathbf{1 b}^{+}$ & $\mathrm{Ph}-\mathrm{C} \equiv \mathrm{CH}$ & $(2)$ & $\mathrm{TiCl}_{4}$ & $3.8[\mathrm{a}]$ \\
& $\mathrm{Ph}-\mathrm{C} \equiv \mathrm{CH}$ & $(2)$ & $\mathrm{BCl}_{3}$ & 3.9 \\
$\mathbf{1 c}^{+}$ & $\mathrm{Ph}-\mathrm{C} \equiv \mathrm{CH}$ & $(2)$ & $\mathrm{TiCl}_{4}$ & $7.2 \times 10^{-2}$ \\
& & & & \\
$\mathbf{1 b}^{+}$ & $\mathrm{Ph}-\mathrm{C} \equiv \mathrm{C}-\mathrm{Me}$ & $(4)$ & $\mathrm{TiCl}_{4}$ & $4.3 \times 10^{1}$ \\
& $\mathrm{Ph}-\mathrm{C} \equiv \mathrm{C}-\mathrm{Me}$ & $(4)$ & $\mathrm{BCl}_{3}$ & $4.6 \times 10^{1}$ \\
& & & & \\
$\mathbf{1 b}^{+}$ & $\mathrm{nC}_{4} \mathrm{H}_{9}-\mathrm{C} \equiv \mathrm{CH}$ & $(6)$ & $\mathrm{TiCl}_{4}$ & $1.6 \times 10^{-2}$ \\
\hline
\end{tabular}

[a] $\Delta H^{\ddagger}=25.56 \pm 0.97 \mathrm{~kJ} \mathrm{~mol}^{-1}, \Delta S^{\neq}=-104.0 \pm 4.2 \mathrm{~J} \mathrm{~mol}^{-1} \mathrm{~K}^{-1}$.

Scheme 3

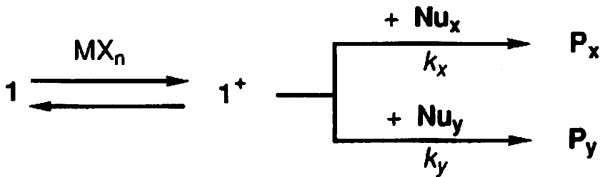

Conductivity measurements indicate that the colored byproducts are of ionic nature, but we have not been able to reveal their identity. Possible explanations such as acid-catalyzed dimerizations of alkynes with formation of cyclobutenylium ions or hydride abstractions from 3, 5, and 7 with formation of aryl-substituted allyl cations, could not be substantiated. These side reactions disturb the initial period of the reactions only slightly, and consistent rate constants have been obtained by monitoring the course of the reactions at a low degree of conversion (see Table 3). As in analogous reactions with alkenes ${ }^{[7]}$ and other vinyl derivatives $^{[12,18]}$, exchange of the carbenium counterion does not significantly affected the reaction rates (Table 1 ).

Nevertheless, a comparison of the individual kinetic runs (Table 3) shows that the averaged $k_{2}$ values given in Table 1 are much less accurate than those previously determined for alkenes ${ }^{[6-9]}$ and allyl-element compounds ${ }^{[12]}$. We have, therefore, considered it necessary to confirm these data by competition experiments which would provide an additional link to the previously reported nucleophilicities of $\mathrm{CC}$ double bond-containing systems.

\section{Determination of Relative Rates}

When carbenium ions are generated in situ in the presence of two nucleophiles, the relative reactivities $\kappa$ can be derived from eq. (1) ${ }^{[19]}$ (Scheme 3). 
Table 2. Relative reactivities of alkynes and alkenes toward diarylmethyl cations in $\mathrm{CH}_{2} \mathrm{Cl}_{2}\left(\mathrm{ZnCl}_{2} \cdot \mathrm{OEt}_{2},-70^{\circ} \mathrm{C}\right)$

\begin{tabular}{|c|c|c|c|}
\hline \multirow{4}{*}{$\frac{\mathrm{Ar}_{2} \mathrm{CHCl}}{1 \mathrm{a}}$} & $\mathrm{Nu} u_{x} / \mathrm{Nu} u_{y}$ & $T /{ }^{\circ} \mathrm{C}$ & $k_{x} / k_{y}$ \\
\hline & $\mathrm{Ph}-\mathrm{CH}=\mathrm{CH}_{2} \mathrm{I}$ & -70 & 214 \\
\hline & $\mathrm{Ph}-\mathrm{C} \equiv \mathrm{CH}$ & -40 & 135 \\
\hline & & $\begin{array}{r}-10 \\
20\end{array}$ & $\begin{array}{l}35.6 \\
28.1\end{array}$ \\
\hline \multirow[t]{2}{*}{$1 b$} & $\mathrm{Ph}-\mathrm{CH}=\mathrm{CH}_{2} /$ & -70 & 164 \\
\hline & $\mathrm{Ph}-\mathrm{C} \equiv \mathrm{CH}$ & $\begin{array}{r}-40 \\
-10 \\
20\end{array}$ & $\begin{array}{l}62.7 \\
27.6 \\
15.7\end{array}$ \\
\hline $1 b$ & $\begin{array}{l}\text { (E)-Ph-CH=CH-CH} / \\
\mathrm{Ph}-\mathrm{C} \equiv \mathrm{C}-\mathrm{CH}_{3}\end{array}$ & -70 & 9.45 \\
\hline $1 b$ & $\begin{array}{l}\mathrm{Cl}\left(\mathrm{CH}_{3}\right) \mathrm{C}=\mathrm{CH}_{2} / \\
\mathrm{n}-\mathrm{C}_{4} \mathrm{H}_{9}-\mathrm{C} \equiv \mathrm{CH}\end{array}$ & -20 & 1.37 \\
\hline
\end{tabular}

The concentrations of the products $\left[\mathrm{P}_{x}\right]$ and $\left[\mathrm{P}_{y}\right]$, which are needed for the calculation of $\kappa$ according to eq. (1), are obtained by HPLC analysis of the product mixtures using an internal standard. On the assumption that 1 is quantitatively converted into $P_{x}$ and $P_{y}$, eq. (1) can be transformed into eq. $(2)^{[20]}$, which allows us to calculate $\kappa$ from the product ratio $R=\left[\mathrm{P}_{x}\right] /\left[\mathrm{P}_{y}\right]$ and does not require the determination of absolute product yields by use of an internal standard (Table 2). Independence of the competition constant of the reactant ratios justifies this procedure.

$$
\kappa=k_{\mathrm{x}} / k_{\mathrm{y}}=\lg \left(1-\frac{[1]_{0} R}{\left[\mathrm{Nu}_{x}\right]_{0}(1+R)}\right) / \lg \left(1-\frac{[1]_{0}}{\left[\mathrm{Nu}_{y}\right]_{0}(1+R)}\right)
$$

\section{Discussion}

In a previous work, a good agreement between relative olefin reactivities derived from direct rate measurements and from competition experiments has been observed, even

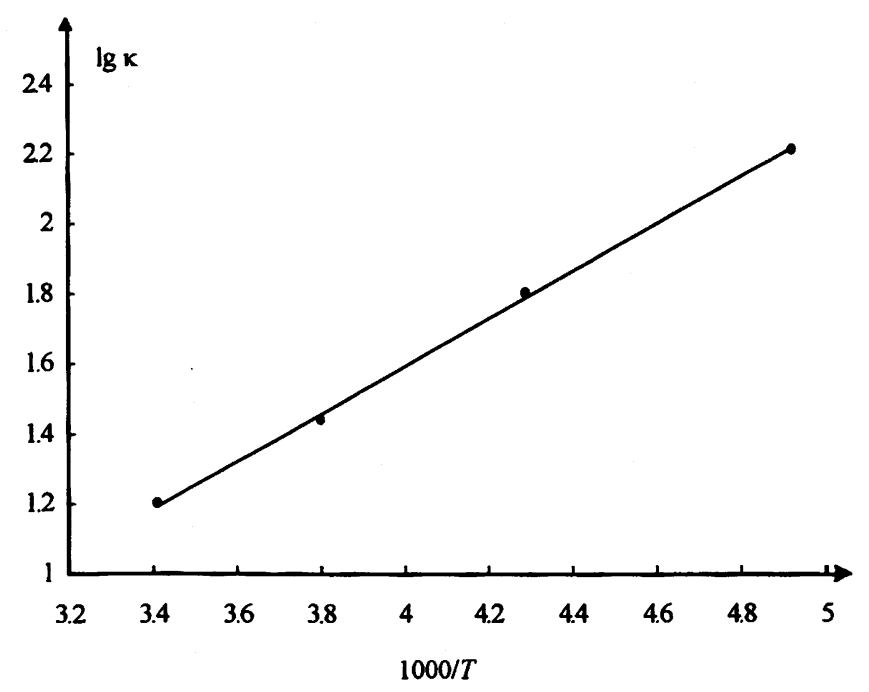

Figure 1. Relative reactivities of styrene/phenylacetylene (2) $\left[\mathrm{K}=\lg \left(k_{\text {styrene }} / k_{\text {phenylacetylene }}\right)\right]$ as a function of temperature
Scheme 4. Reactivity scale for $\pi$ nucleophiles toward ( $p$ $\left.\mathrm{MeC}_{6} \mathrm{H}_{4}\right)_{2} \mathrm{CH}^{+}$at $-70^{\circ} \mathrm{C}$ (based on absolute rate constants)
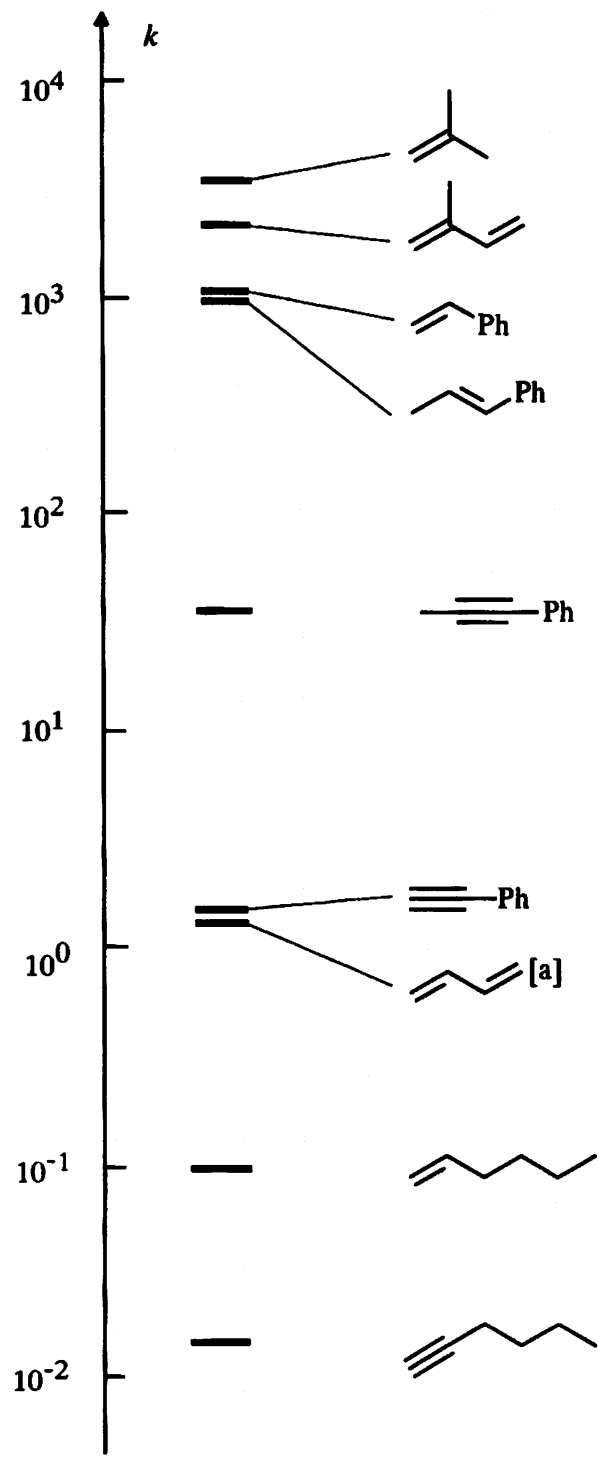

[a] Extrapolated value.

when different Lewis acids were employed for the ionization of the benzhydryl chlorides. We have now found a styrene/ phenylacetylene (2) reactivity ratio of $277\left(\mathrm{Tol}_{2} \mathrm{CH}^{+}\right.$, $-70^{\circ} \mathrm{C}$ ) from directly measured rates (counterion $\mathrm{BCl}_{4}^{-}$or $\mathrm{TiCl}_{5}{ }_{5}$, Table 1 and ref. ${ }^{[9]}$ ) and of 164 (counterion $\mathrm{ZnCl}_{3}^{-}$) from competition experiments. Under the same conditions trans-1-phenyl-1-propene has been found to be 22 times more reactive than 1-phenyl-1-propyne (4) on the basis of absolute rate constants (counterion $\mathrm{BCl}_{4}^{-}$or $\mathrm{TiCl}_{5}^{-}$, Table 1 and ref. ${ }^{[9]}$, while competition experiments yield the smaller ratio of 9.5 (counterion $\mathrm{ZnCl}_{3}^{-}$). Though the deviations between the two methods are unusually large for these examples, probably because of the problems connected with the determination of absolute rate constants for alkynes, one can now be sure that the order of magnitude determined for alkyne reactivities is correct. Rough agreement between competition experiments $\left(k_{\mathrm{x}} / k_{\mathrm{y}}=1.37\right.$ at $\left.-20^{\circ} \mathrm{C}\right)$ 
Table 3. Kinetics of the reactions of diarylmethyl cations with alkynes

\begin{tabular}{|c|c|c|c|c|c|c|c|}
\hline 1 & $\begin{array}{l}{[1]_{0}^{\prime} /} \\
\mathrm{mol} \mathrm{l-1}\end{array}$ & $\begin{array}{l}\text { [alkyne]o / } \\
\text { mol l-1 }\end{array}$ & $\begin{array}{l}\text { Lewis } \\
\text { acid }\end{array}$ & $\begin{array}{c}\text { [Lewis acid] }]_{0} / \\
\mathrm{mol} \mathrm{I}^{-1}\end{array}$ & $T /{ }^{\circ} \mathrm{C}$ & $\begin{array}{l}\text { Quantity observed } \\
\text { (up to } \% \text { conversion)[a] }\end{array}$ & $k_{2} / 1 \mathrm{~mol}^{-1} \mathrm{~s}^{-1}[\mathrm{~b}]$ \\
\hline \multicolumn{8}{|c|}{ Phenylacetylene (2) } \\
\hline $1 \mathrm{a}$ & $\begin{array}{l}4.6 \times 10^{-5} \\
4.6 \times 10^{-5}\end{array}$ & $\begin{array}{l}1.1 \times 10^{-3} \\
5.3 \times 10^{-4}\end{array}$ & $\begin{array}{l}\mathrm{TiCl}_{4} \\
\mathrm{TiCl} 4\end{array}$ & $\begin{array}{l}3.7 \times 10^{-2} \\
3.7 \times 10^{-2}\end{array}$ & $\begin{array}{l}-70 \\
-70\end{array}$ & $\begin{array}{l}A(81) / C(54) \\
A(79) / C(52)\end{array}$ & $\begin{array}{l}4.52 \times 10^{2} / 3.27 \times 10^{2} \\
4.42 \times 10^{2} / 3.19 \times 10^{2}\end{array}$ \\
\hline $1 \mathrm{~b}$ & $\begin{array}{l}6.7 \times 10^{-5} \\
6.0 \times 10^{-5} \\
1.1 \times 10^{-4} \\
6.0 \times 10^{-5} \\
5.4 \times 10^{-5} \\
5.4 \times 10^{-5} \\
5.4 \times 10^{-5} \\
5.4 \times 10^{-5} \\
5.4 \times 10^{-5} \\
5.4 \times 10^{-5}\end{array}$ & $\begin{array}{l}5.5 \times 10^{-4} \\
4.8 \times 10^{-4} \\
1.1 \times 10^{-3} \\
5.5 \times 10^{-4} \\
5.5 \times 10^{-4} \\
4.3 \times 10^{-4} \\
5.5 \times 10^{-4} \\
8.3 \times 10^{-4} \\
5.5 \times 10^{-4} \\
4.3 \times 10^{-4}\end{array}$ & $\begin{array}{l}\mathrm{TiCl}_{4} \\
\mathrm{TiCl}_{4} \\
\mathrm{BCl}_{3} \\
\mathrm{BCl}_{3} \\
\mathrm{TiCl}_{4} \\
\mathrm{TiCl}_{4} \\
\mathrm{TiCl}_{4} \\
\mathrm{TiCl}_{4} \\
\mathrm{TiCl}_{4} \\
\mathrm{TiCl}_{4}\end{array}$ & $\begin{array}{l}7.1 \times 10^{-4} \\
5.5 \times 10^{-4} \\
1.3 \times 10^{-2} \\
2.6 \times 10^{-2} \\
1.2 \times 10^{-4} \\
1.2 \times 10^{-4} \\
1.2 \times 10^{-3} \\
1.2 \times 10^{-3} \\
1.2 \times 10^{-3} \\
1.2 \times 10^{-3}\end{array}$ & $\begin{array}{l}-70 \\
-70 \\
-70 \\
-70 \\
-40 \\
-40 \\
-10 \\
-10 \\
+20 \\
+20\end{array}$ & $\begin{array}{l}A(62) / C(23) \\
A(62) / C(24) \\
A(60) / C(24) \\
A(59) / C(23) \\
A(25) \\
A(24) \\
A(26) \\
A(25) \\
A(47) \\
A(45)\end{array}$ & $\begin{array}{l}3.93 / 3.71 \\
3.86 / 3.60 \\
3.89 / 3.88 \\
3.77 / 3.73 \\
4.50 \times 10^{1} \\
4.46 \times 10^{1} \\
2.06 \times 10^{2} \\
2.06 \times 10^{2} \\
4.98 \times 10^{2} \\
4.87 \times 10^{2}\end{array}$ \\
\hline $1 \mathrm{c}$ & $\begin{array}{l}8.0 \times 10^{-5} \\
2.0 \times 10^{-4} \\
9.8 \times 10^{-5}\end{array}$ & $\begin{array}{l}5.2 \times 10^{-3} \\
1.1 \times 10^{-3} \\
1.0 \times 10^{-3}\end{array}$ & $\begin{array}{l}\mathrm{TiCl}_{4} \\
\mathrm{TiCl}_{4} \\
\mathrm{BCl}_{3}\end{array}$ & $\begin{array}{l}8.0 \times 10^{-4} \\
8.0 \times 10^{-4} \\
2.7 \times 10^{-2}\end{array}$ & $\begin{array}{l}-70 \\
-70 \\
-70\end{array}$ & $\begin{array}{l}A(17) / C(13) \\
A(17) / C(12) \\
A(57)\end{array}$ & $\begin{array}{l}7.8 \times 10^{-2} / 6.4 \times 10^{-2} \\
7.1 \times 10^{-2} / 6.9 \times 10^{-2} \\
8.0 \times 10^{-2}[\mathrm{c}]\end{array}$ \\
\hline \multicolumn{8}{|c|}{ 1-Phenyl-1-propyne (4) } \\
\hline $1 \mathrm{~b}$ & $\begin{array}{l}6.7 \times 10^{-5} \\
6.7 \times 10^{-5} \\
6.7 \times 10^{-5} \\
6.7 \times 10^{-5}\end{array}$ & $\begin{array}{l}5.7 \times 10^{-4} \\
7.5 \times 10^{-4} \\
5.7 \times 10^{-4} \\
7.5 \times 10^{-4}\end{array}$ & $\begin{array}{l}\mathrm{TiCl}_{4} \\
\mathrm{TiCl}_{4} \\
\mathrm{BCl}_{3} \\
\mathrm{BCl}_{3}\end{array}$ & $\begin{array}{l}6.9 \times 10^{-4} \\
6.9 \times 10^{-4} \\
2.6 \times 10^{-2} \\
2.6 \times 10^{-2}\end{array}$ & $\begin{array}{l}-70 \\
-70 \\
-70 \\
-70\end{array}$ & $\begin{array}{l}A(18) / C(19) \\
A(19) / C(19) \\
A(32) / C(34) \\
A(33) / C(34)\end{array}$ & $\begin{array}{l}6.23 \times 10^{1} / 4.29 \times 10^{1} \\
6.14 \times 10^{1} / 4.29 \times 10^{1} \\
6.16 \times 10^{1} / 4.62 \times 10^{1} \\
6.05 \times 10^{1} / 4.82 \times 10^{1}\end{array}$ \\
\hline \multicolumn{8}{|c|}{ 1-Hexyne (6) } \\
\hline $1 b$ & $\begin{array}{l}6.1 \times 10^{-5} \\
6.0 \times 10^{-5} \\
\end{array}$ & $\begin{array}{l}5.2 \times 10^{-4} \\
5.2 \times 10^{-4} \\
\end{array}$ & $\begin{array}{l}\mathrm{TiCl}_{4} \\
\mathrm{TiCl}_{4}\end{array}$ & $\begin{array}{l}6.9 \times 10^{-4} \\
7.4 \times 10^{-4} \\
\end{array}$ & $\begin{array}{l}-70 \\
-70 \\
\end{array}$ & $\begin{array}{l}A(7) / C(17) \\
A(8) / C(22)\end{array}$ & $\begin{array}{l}1.43 \times 10^{-2} / 1.85 \times 10^{-2} \\
1.32 \times 10^{-2} / 2.2 \times 10^{-2}\end{array}$ \\
\hline
\end{tabular}

[a] $\mathrm{A}=$ determination of absorbance; $\mathrm{C}=$ determination of conductance. $-{ }^{[\mathrm{b}]}$ If two values are given, the first refers to absorbance, the second to conductance. $-[\mathrm{c}]$ Reaction performed in the presence of $\left[\right.$ TEBA] $=4.39 \cdot 10^{-3} \mathrm{~mol} \mathrm{l}^{-1}$.

and the results of absolute rate determinations $\left(k_{\mathrm{x}} / k_{\mathrm{y}}=1.7\right.$ at $-70^{\circ} \mathrm{C}$ ) has also been found for the couple 2-chloro-1propene/1-hexyne (6), when a preliminary rate constant for the reaction of $1 \mathrm{~b}$ with 2-chloro-1-propene $\left(2.7 \cdot 10^{-2} 1\right.$ $\left.\mathrm{mol}^{-1} \mathrm{~s}^{-1},-70^{\circ} \mathrm{C}\right)^{[21]}$ is employed.

A further congruence of both methods is noticeable. While $\Delta S^{\neq}$for the reaction of diarylcarbenium ions with styrene has been determined to be $-122 \pm 5 \mathrm{~J} \mathrm{~mol}^{-1} \mathrm{~K}^{-1}$, similar to other terminal vinyl derivatives ${ }^{[8]}$, the activation entropy for the reaction of $1 \mathrm{~b}$ with phenylacetylene $(-104 \mathrm{~J}$ $\mathrm{mol}^{-1} \mathrm{~K}^{-1}$ ) has been found to be considerably less negative, indicating a less ordered transition state for carbenium ion additions to alkynes than to alkenes. On the other hand, $\Delta H^{\ddagger}$ is greater for additions to phenylacetylene (2) than to styrene with the consequence that the alkyne additions have a higher temperature gradient than the alkene additions. This effect is also observed in competition experiments at variable temperature (Table 2): While styrene is two orders of magnitude more reactive than phenylacetylene (2) at $-70^{\circ} \mathrm{C}$, this ratio reduces to one order of magnitude at $20^{\circ} \mathrm{C}$, and one can extrapolate that a $T \geqslant 300^{\circ} \mathrm{C} 2$ would react faster with diarylmethyl cations than styrene. An Eyring plot of the relative rates of the reaction of styrene and 2 with $1 \mathrm{~b}$ (Figure 1) yields $\Delta \Delta H^{+}=13.0 \mathrm{~kJ} \mathrm{~mol}^{-1}$ and $\Delta \Delta S^{\neq}=21.6 \mathrm{~J} \mathrm{~mol}^{-1} \mathrm{~K}^{-1}$, which agrees fairly well with the average $\Delta \Delta S^{\neq}$of $18 \mathrm{~J} \mathrm{~mol}^{-1} \mathrm{~K}^{-1}$ derived from measurements of absolute rates.

It is now clear that different reaction temperatures are the main reason for the deviating alkene/alkyne reactivity ratio observed by Modena $\left(40^{\circ} \mathrm{C}\right.$, competition method) and by our group $\left(-70^{\circ} \mathrm{C}\right.$, direct rate measurements). An explanation why the alkene/alkyne ratios determined in this work are still somewhat larger than the previously reported reactivity ratios ${ }^{[4]}$ is hard to find, as details of the evaluation of the previous experiments have not been given ${ }^{[4]}$. Possibly it is due to the fact that the previous experiments ${ }^{[4]}$ have been performed under heterogeneous conditions.

\section{Conclusion}

A comparison of the rate constants for the reactions of the bis(4-methylphenyl)methyl cation (1b) with various $\pi$ nucleophiles (Scheme 4) shows that at $-70^{\circ} \mathrm{C}$ alkynes are somewhat less reactive than structurally analogous alkenes. As previously discussed by Modena ${ }^{[4,5]}$, the reactivity of alkynes toward carbenium ions is comparable to that of ordinary alkenes, and alkynes cannot generally be regarded as weak nucleophiles. The ranking in Scheme 4 is only slightly affected when relative rates from competition experiments are used as the basis. Since the relative reactivity of styrene and phenylacetylene changes only slightly, when different reference electrophiles are employed (Table 1 and ref. ${ }^{[9]}$ ), one can conclude that the reactivity order in Scheme 4 also holds roughly for other carbon electrophiles. It has to be kept in mind, however, that the relative reactivities of styrene/phenylacetylene and trans-1-phenyl-1-propene/1-phenyl-1-propyne (4) decrease dramatically as the temperature is increased, implying that the nucleophilicity order in Scheme 4 is strongly affected by temperature. 
We thank Ms. M. Deters and Ms. H. Freter for experimental assistance (HPLC separations), the Deutsche Forschungsgemeinschaft and the Fonds der Chemischen Industrie for financial support.

\section{Experimental}

NMR: XL 200 (Varian) and WM 300 (Bruker). - MS: 70-250 E (VG-Instruments). - UV: Beckmann Spectrophotometer UV 5240. - HPLC: Knauer HPLC pump 64 with Rheodyne 7125 valve, steel column $(250 \times 4 \mathrm{~mm})$ filled with LiChrospher $100 \mathrm{RP}$ 18 (5- $\mu \mathrm{m}$ particles).' - All alkynes and alkenes are commercially available. The diarylchloromethanes $1 \mathrm{a}-\mathrm{c}$ were prepared by treatment of the corresponding diarylmethanols with $\mathrm{HCl}^{[22]}$.

\section{Preparation of the Addition Products}

Chlorodiphenylmethane (1a) and Phenylacetylene (2): The reaction was carried out as described in ref. ${ }^{[15]}$ to give $62 \%$ of a mixture of $(E)$-3a and $(Z)-3 a$ (9:1) from which $(E)-3 a$ was isolated by fractional crystallization from ethanol: (E)-1-Chloro-1,3,3-triphenyl-1propene $[(E)-3 \mathrm{a}]$ : Colorless crystals with m.p. $65-66^{\circ} \mathrm{C}$ (ref. ${ }^{[15]}$ $\left.65-66^{\circ} \mathrm{C}\right) .-{ }^{1} \mathrm{H}$ NMR $\left(\mathrm{CDCl}_{3}, 300 \mathrm{MHz}\right): \delta=4.78(\mathrm{~d}, J=11.0$ $\mathrm{Hz}, 1 \mathrm{H}, 3-\mathrm{H}), 6.45$ (d, $J=11.0 \mathrm{~Hz}, 1 \mathrm{H}, 2-\mathrm{H}), 7.11-7.36(\mathrm{~m}, 15 \mathrm{H}$, aromatic $\mathrm{H}) .-{ }^{13} \mathrm{C} \mathrm{NMR}\left(\mathrm{CDCl}_{3}\right): \delta=50.8$ (d), 126.7 (d), 128.2 (d), 128.4 (d), 128.7 (d), 128.9 (d), 129.6 (d), 131.5 (d), 131.6 (s), 137.0 (s), 143.4 (s). - UV (methanol): $\lambda_{\max }(\lg \varepsilon)=246 \mathrm{~nm}$ (3.962), $263(\mathrm{sh}), 269$ (sh).

Pure (Z)-3a, which is needed for the HPLC analysis of the competition experiments (see below), was obtained by fractional recrystallization (ethanol) of a 10:1 mixture of $(Z)-3 \mathbf{a}$ and $(E)-3 \mathbf{a}$. This mixture was prepared as described in ref. ${ }^{[15]}$ by treatment of $1,3,3-$ triphenyl-1-propanone with $\mathrm{PCl}_{5}$ and subsequently with $\mathrm{NEt}_{3}$. (Z)-1-Chloro-1,3,3-triphenyl-1-propene [(Z)-3a]: Colorless crystals with m.p. $77-79^{\circ} \mathrm{C}$ (ethanol). $-{ }^{1} \mathrm{H} \mathrm{NMR}\left(\mathrm{CDCl}_{3}, 300 \mathrm{MHz}\right): \delta=$ $5.42(\mathrm{~d}, J=9.5 \mathrm{~Hz}, 1 \mathrm{H}, 3-\mathrm{H}), 6.60(\mathrm{~d}, J=9.5 \mathrm{~Hz}, 1 \mathrm{H}, 2-\mathrm{H})$, 7.11-7.61 (m, 15 H, aromatic $\mathrm{H}) .-{ }^{13} \mathrm{C} \mathrm{NMR}\left(\mathrm{CDCl}_{3}\right): \delta=50.8$ (d), 126.6 (d), 128.3 (d), 128.6 (d), 129.6 (d), 133.4 (s), 137.9 (s), 143.0 (s). - UV (methanol): $\lambda_{\max }(\lg \varepsilon)=253 \mathrm{~nm}$ (4.267), 264 (sh), 270 (sh), 291 (sh).

Chlorobis(4-methylphenyl)methane (1b) and Phenylacetylene (2): A solution of $1 \mathrm{~b}(1.37 \mathrm{~g}, 5.94 \mathrm{mmol})$ in $\mathrm{CH}_{2} \mathrm{Cl}_{2}(5 \mathrm{ml})$ was added dropwise to a cooled solution $\left(-20^{\circ} \mathrm{C}\right)$ of $2(613 \mathrm{mg}, 6.00 \mathrm{mmol})$ and $\mathrm{ZnCl}_{2}\left(\mathrm{OEt}_{2}\right)_{1.6}(1.20 \mathrm{mmol})^{[23]}$ in $\mathrm{CH}_{2} \mathrm{Cl}_{2}(20 \mathrm{ml})$. After $3.5 \mathrm{~h}$ the mixture was poured into $20 \mathrm{ml}$ of conc. aqueous ammonia. The aqueous phase was extracted with $5 \mathrm{ml}$ of $\mathrm{CH}_{2} \mathrm{Cl}_{2}$, and the combined organic phases were dried with $\mathrm{MgSO}_{4}$ and concentrated to give $1.82 \mathrm{~g}(92 \%)$ of crude $(E, Z)-3 \mathrm{~b}$ (7:1, determined by ${ }^{1} \mathrm{H}-\mathrm{NMR}$ analysis). Two crystallizations from ethanol gave a pure sample of the $(E)$ isomer. (E)-1-Chloro-3,3-bis(4-methylphenyl)-1-phenyl-1propene $[(E)-3 \mathrm{~b}]$ : Colorless needles with m.p. $81-83^{\circ} \mathrm{C}$. $-{ }^{1} \mathrm{H}$ $\mathrm{NMR}\left(\mathrm{CDCl}_{3}, 300 \mathrm{MHz}\right): \delta=2.32\left(\mathrm{~s}, 6 \mathrm{H}, \mathrm{CH}_{3}\right), 4.70(\mathrm{~d}, J=$ $11.0 \mathrm{~Hz}, 1 \mathrm{H}, 3-\mathrm{H}), 6.41$ (d, $J=11.0 \mathrm{~Hz}, 1 \mathrm{H}, 2-\mathrm{H}), 6.99-7.35$ (m, $13 \mathrm{H}$, aromatic $\mathrm{H}) .-{ }^{13} \mathrm{C} \mathrm{NMR}\left(\mathrm{CDCl}_{3}\right): \delta=21.0(\mathrm{q}), 49.9$ (d), 128.0 (d), 128.3 (d), 128.6 (d), 128.8 (d), 129.3 (d), 131.0 (s), 131.7 (d), 136.1 (s), 137.0 (s), 140.5 (s). - UV (methanol): $\lambda_{\max }(\lg \varepsilon)=$ $222 \mathrm{~nm}$ (4.354), 246 (4.017, sh), 266 (sh), 275 (3.508, sh). - MS $(70 \mathrm{eV}), \mathrm{m} / \mathrm{z}(\%): 334,332(4,9)\left[\mathrm{M}^{+}\right], 317(4), 297(100), 296(17)$, 281 (14), 204 (71), 165 (17), 105 (17). $-\mathrm{C}_{23} \mathrm{H}_{21} \mathrm{Cl}$ : calcd. 332.1332; found 332.1346 (MS).

$(Z)$-3b was not isolated as a pure compound and was detected in the $300-\mathrm{MHz}^{1} \mathrm{H}-\mathrm{NMR}$ spectrum by the resonances of $2-\mathrm{H}(\delta=$ $6.59, \mathrm{~d}, J=9.0 \mathrm{~Hz})$ and $3-\mathrm{H}(\delta=5.36, \mathrm{~d}, J=9.0 \mathrm{~Hz})$.

Chloro(4-methoxyphenyl)phenylmethane (1c) and Phenylacetylene (2): A solution of $1 \mathrm{c}(900 \mathrm{mg}, 3.87 \mathrm{mmol})$ in $\mathrm{CH}_{2} \mathrm{Cl}_{2}(10 \mathrm{ml})$ was added dropwise to a solution of $2(2.00 \mathrm{~g}, 19.6 \mathrm{mmol})$ and
$\mathrm{ZnCl}_{2}(54 \mathrm{mg})$ in $20 \mathrm{ml}$ of $\mathrm{CH}_{2} \mathrm{Cl}_{2}$. After $6 \mathrm{~h}\left(40^{\circ} \mathrm{C}\right)$ the mixture was poured into $20 \mathrm{ml}$ of conc. aqueous ammonia. The aqueous phase was extracted with $5 \mathrm{ml}$ of $\mathrm{CH}_{2} \mathrm{Cl}_{2}$, and the combined organic phases were dried with $\mathrm{MgSO}_{4}$ and concentrated to give 800 $\mathrm{mg}(62 \%)$ of oily $(E, Z)-3 \mathrm{c}\left(8: 1\right.$, determined by ${ }^{1} \mathrm{H}-\mathrm{NMR}$ analysis). (E)-1-Chloro-3-(4-methoxyphenyl)-1,3-diphenyl-1-propene: ${ }^{1} \mathrm{H}$ $\mathrm{NMR}\left(\mathrm{CDCl}_{3}, 300 \mathrm{MHz}\right): \delta=3.70\left(\mathrm{~s}, 3 \mathrm{H}, \mathrm{OCH}_{3}\right), 4.65(\mathrm{~d}, J=$ $10.5 \mathrm{~Hz}, 1 \mathrm{H}, 3-\mathrm{H}), 6.39$ (d, $J=10.5 \mathrm{~Hz}, 1 \mathrm{H}, 2-\mathrm{H}), 6.6-7.7(\mathrm{~m}$, $14 \mathrm{H}$, aromatic $\mathrm{H})$.

(Z)-3c was detected in the $300-\mathrm{MHz}{ }^{1} \mathrm{H}-\mathrm{NMR}$ spectrum by the resonance of $3-\mathrm{H}(\delta=5.18, \mathrm{~d}, J=10.0 \mathrm{~Hz})$.

Chlorobis(4-methylphenyl)methane (1b) and 1-Phenyl-1-propyne (4): A solution of $\mathrm{ZnCl}_{2}\left(\mathrm{OEt}_{2}\right)_{1.6}(1.4 \mathrm{mmol})$ in $0.5 \mathrm{ml}$ of $\mathrm{CH}_{2} \mathrm{Cl}_{2}$ was added to a cold $\left(-70^{\circ} \mathrm{C}\right)$ solution of $1 \mathrm{~b}(1.50 \mathrm{~g}, 6.50 \mathrm{mmol})$ and $4(1.85 \mathrm{~g}, 15.9 \mathrm{mmol})$ in $\mathrm{CH}_{2} \mathrm{Cl}_{2}(25 \mathrm{ml})$. After $15 \mathrm{~h}$ the deepred solution was worked up as described above, and the mixture was purified by liquid chromatography (RP 18, methanol) to give $(E)-5 b(1.80 \mathrm{~g}, 80 \%)$ and $0.18 \mathrm{~g}$ of a second fraction containing (Z)-5b and a cyclic compound. (E)-1-Chloro-2-methyl-3,3-bis(4methylphenyl)-1-phenyl-1-propene [ $(E)-5 \mathrm{~b}]:$ Colorless needles with m.p. $205^{\circ} \mathrm{C}$ (ethanol). ${ }^{1} \mathrm{H} \mathrm{NMR}\left(\mathrm{CDCl}_{3}, 200 \mathrm{MHz}\right): \delta=1.89$ (s, 3H, 2- $\left.\mathrm{CH}_{3}\right), 2.34\left(\mathrm{~s}, 6 \mathrm{H}\right.$, aryl- $\left.\mathrm{CH}_{3}\right), 5.07(\mathrm{~s}, 1 \mathrm{H}, 3-\mathrm{H})$, 6.93-7.32 (m, 13 H, aromatic $\mathrm{H}) .-{ }^{13} \mathrm{C} \mathrm{NMR:} \delta=17.7$ (q), 21.0 (q), 53.2 (d), 128.2 (d), 128.4 (d), 128.8 (d), 128.9 (d), 135.2 (s), 135.9 (s), 139.0 (s), 139.0 (s). - MS (70 eV), m/z (\%): 348, 346 (7, 20) $\left[\mathrm{M}^{+}\right], 311$ (83), 310 (22), 295 (23), 219 (100), 195 (16). $\mathrm{C}_{24} \mathrm{H}_{23} \mathrm{Cl}$ : calcd. 346.1488; found 346.1487 (MS).

Chlorobis(4-methylphenyl)methane (1b) and 1-Hexyne (6): At ambient temperature, a solution of $1 \mathrm{~b}(1.90 \mathrm{~g}, 8.23 \mathrm{mmol})$ in $\mathrm{CH}_{2} \mathrm{Cl}_{2}(5 \mathrm{ml})$ was added dropwise $(5 \mathrm{~min})$ to a solution of $6(2.10$ $\mathrm{g}, 25.6 \mathrm{mmol})$ and $\mathrm{ZnCl}_{2}\left(\mathrm{Et}_{2} \mathrm{O}\right)_{1.6}(5.0 \mathrm{mmol})$ in $\mathrm{CH}_{2} \mathrm{Cl}_{2}(10 \mathrm{ml})$. After $15 \mathrm{~h}$, the dark-red mixture was worked up as described above, and an HPLC analysis indicated the production of $(E, Z)-7 \mathbf{b}$ and of oligomers. Short-path distillation $\left(180^{\circ} \mathrm{C} / 6 \cdot 10^{-4} \mathrm{~Pa}\right)$ and chromatographic purification (RP 18, methanol) yielded $0.80 \mathrm{~g} \mathrm{(31 \% )}$ of a 1:1 mixture of $(E)-7 \mathrm{~b}$ and $(Z)-7 \mathrm{~b}$ which was not separated. (E,Z)-3-Chloro-1,1-bis(4-methylphenyl)-2-heptene [(E,Z)-7b]: ${ }^{1} \mathrm{H}$ NMR $\left(\mathrm{CDCl}_{3}, 200 \mathrm{MHz}\right): \delta=0.88,0.91(2 \mathrm{t}, J=7.2 \mathrm{~Hz}, 6 \mathrm{H}, E /$ Z-7-H), 1.30-1.57 (m, 8H, E/Z-5-H, E/Z-6-H), 2.32 (s, 12 H, aryl$\mathrm{CH}_{3}$ ), 2.37, 2.43 (2 t, $\left.J=7 \mathrm{~Hz}, 4 \mathrm{H}, E / Z-4-\mathrm{H}\right), 4.79$ (d, $J=10.2$ $\mathrm{Hz}, 1 \mathrm{H}, E-1-\mathrm{H}$ ), 5.15 (d, $J=9.6 \mathrm{~Hz}, 1 \mathrm{H}, Z-1-\mathrm{H}$ ), 5.93 (d, $J=9.6$ $\mathrm{Hz}, 1 \mathrm{H}, Z-2-\mathrm{H}), 6.06$ (d, $J=10.2 \mathrm{~Hz}, 1 \mathrm{H}, E-2-\mathrm{H}), 7.02-7.25$ (m, $16 \mathrm{H}$, aromatic $\mathrm{H}) .-{ }^{13} \mathrm{C}$ NMR $\left(\mathrm{CDCl}_{3}\right): \delta=13.83,13.92(2 \mathrm{q}$, C-7), 21.00 (q, aryl- $\mathrm{CH}_{3}$ ), 21.75, 21.98 (2 t, C-6), 29.44, 29.53 (2 t, C-5), 33.70, 39.28 (2 t, C-4), 49.04, 49.10 (2 d, C-1), 127.68, 130.20 (2 d, C-2), 127.93, 128.01, 129.14, 129.21 (4 d, Co $\mathrm{C}_{m}$ ), 135.05, 135.30 (2 s, C-3), 135.83, 136.00 (2 s, $\mathrm{C}_{p}$ ), 140.56, 140.68 (2 s, $\left.\mathrm{C}_{i}\right)$. $-\mathrm{C}_{21} \mathrm{H}_{25} \mathrm{Cl}$ : calcd. 312.1645; found 312.1643 (MS).

1-Chloro-1,3,3-triphenylpropane (8a) was synthesized from 1a and styrene as described in ref. ${ }^{[16]}-{ }^{13} \mathrm{C} \mathrm{NMR}\left(\mathrm{CDCl}_{3}\right): \delta=45.7$ (t, C-2), 48.4 (d, C-3), 61.6 (d, C-1), 126.5 (d), 126.6 (d), 127.0 (d), 127.8 (d), 127.9 (d), 128.4 (d), 128.6 (d), 128.7 (d), 141.5 (s), 143.3 (s), 143.6 (s). - UV (methanol): $\lambda_{\max }(\lg \varepsilon)=249 \mathrm{~nm}$ (2.694), 254 (2.782), 259 (2.848), 262 (sh), 265 (2.771), 269 (2.671).

1-Chloro-3,3-bis (4-methylphenyl)-1-phenylpropane (8b) was prepared from $1 \mathrm{~b}$ and styrene as reported in ref. ${ }^{[17]}$ where also analytical data are given.

$\left(1 R^{*}, 2 S^{*}\right)-1-C h l o r o-2-m e t h y l-3,3-b i s(4-m e t h y l p h e n y l)-1-p h e n y l-$ propane (9b): For synthesis and analytical data see ref. ${ }^{[24]}$

3,3-Dichloro-1,1-bis(4-methylphenyl)butane (10b): 2-Chloro-1propene $(1.10 \mathrm{~g}, 14.4 \mathrm{mmol})$ and compound $1 \mathrm{~b}(0.70 \mathrm{~g}, 3.0 \mathrm{mmol})$ 
Table 4. Determination of relative reactivities by competition experiments ${ }^{[a]}$

\begin{tabular}{|c|c|c|c|c|c|c|c|}
\hline $\begin{array}{l}T / \\
{ }^{\circ} \mathrm{C}\end{array}$ & $1 / \mathrm{mg}$ & $\mathrm{Nu}_{\mathrm{x}} / \mathrm{mg}$ & $\mathrm{Nu} / \mathrm{mg}$ & Standard / mg & \multicolumn{2}{|c|}{$\begin{array}{l}\text { Products } / \mathrm{mmol} \text { or } \\
\text { molar ratio }\end{array}$} & $k_{x} / k_{y}$ \\
\hline $\begin{array}{l}20 \\
20 \\
20\end{array}$ & $\begin{array}{l}1 \mathrm{a} \\
66.3 \\
65.6 \\
61.4\end{array}$ & $\begin{array}{l}\text { Styrene } \\
62.2 \\
63.5 \\
62.7\end{array}$ & $\begin{array}{c}\text { Phenylacetylene (2) } \\
104.2 \\
154.8 \\
305.9\end{array}$ & $\begin{array}{l}- \\
-\end{array}$ & \multicolumn{2}{|c|}{$\begin{array}{l}60: 6: 1 \\
32: 6: 1\end{array}$} & $\begin{array}{l}27.1 \\
28.3 \\
28.8\end{array}$ \\
\hline-10 & 60.4 & 62.8 & 151.9 & - & \multicolumn{2}{|c|}{$98: 8: 1$} & 35.6 \\
\hline-40 & 64.1 & 65.3 & 160.6 & - & \multicolumn{2}{|c|}{$273: 6: 1$} & 134.5 \\
\hline $\begin{array}{l}-70 \\
-70 \\
-70\end{array}$ & $\begin{array}{l}66.5 \\
59.9 \\
64.4\end{array}$ & $\begin{array}{l}62.2 \\
62.7 \\
63.2\end{array}$ & $\begin{array}{l}124.0 \\
155.6 \\
303.0\end{array}$ & $\begin{array}{l}- \\
-\end{array}$ & \multicolumn{2}{|c|}{$\begin{array}{l}487: 6: 1 \\
527: 7: 1 \\
247: 7: 1\end{array}$} & $\begin{array}{l}203.2 \\
227.7 \\
210.3\end{array}$ \\
\hline $\begin{array}{l}20 \\
20 \\
20\end{array}$ & $\begin{array}{l}1 \mathrm{~b} \\
61.6 \\
85.4 \\
62.8\end{array}$ & $\begin{array}{l}\text { Styrene } \\
63.5 \\
63.5 \\
68.5\end{array}$ & $\begin{array}{c}\text { Phenylacetylene (2) } \\
105.0 \\
172.1 \\
303.9\end{array}$ & $\begin{array}{l}- \\
-\end{array}$ & \multicolumn{2}{|c|}{$\begin{array}{l}46: 5: 1 \\
27: 6: 1 \\
28: 8: 1\end{array}$} & $\begin{array}{l}16.2 \\
14.3 \\
16.6\end{array}$ \\
\hline $\begin{array}{l}-10 \\
-40\end{array}$ & $\begin{array}{l}72.7 \\
76.1\end{array}$ & $\begin{array}{l}64.9 \\
64.8\end{array}$ & $\begin{array}{l}163.3 \\
164.6\end{array}$ & $\begin{array}{l}- \\
-\end{array}$ & \multicolumn{2}{|c|}{$\begin{array}{c}57: 6: 1 \\
123: 6: 1\end{array}$} & $\begin{array}{l}27.6 \\
62.7\end{array}$ \\
\hline $\begin{array}{l}-70 \\
-70 \\
-70\end{array}$ & $\begin{array}{l}63.8 \\
73.2 \\
74.0\end{array}$ & $\begin{array}{l}67.2 \\
64.3 \\
68.4\end{array}$ & $\begin{array}{l}102.9 \\
155.2 \\
309.4\end{array}$ & $\begin{array}{l}- \\
-\end{array}$ & \multicolumn{2}{|c|}{$\begin{array}{l}503: 5: 1 \\
366: 7: 1 \\
238: 8: 1\end{array}$} & $\begin{array}{l}170.1 \\
156.3 \\
164.4\end{array}$ \\
\hline & $1 \mathrm{~b}$ & $\begin{array}{l}\text { trans-1-Phenyl- } \\
\text { 1-propene }\end{array}$ & 1-Phenyl-1-propyne & Methyl benzoate & $9 \mathrm{~b}$ & $5 b[d]$ & \\
\hline \multirow[t]{2}{*}{$\begin{array}{l}-70 \\
-70 \\
-70\end{array}$} & $\begin{array}{l}78.5 \\
78.5 \\
78.5\end{array}$ & $\begin{array}{l}141 \\
123 \\
109\end{array}$ & $\begin{array}{l}418 \\
603 \\
1067\end{array}$ & $\begin{array}{l}39.1 \\
45.3 \\
47.4\end{array}$ & $\begin{array}{l}0.215 \\
0.200 \\
0.154\end{array}$ & $\begin{array}{l}0.0707 \\
0.124 \\
0.176\end{array}$ & $\begin{array}{l}9.99 \\
8.90 \\
9.45\end{array}$ \\
\hline & $1 \mathrm{~b}$ & $\begin{array}{l}\text { 2-Chloro-1- } \\
\text { propene }\end{array}$ & 1-Hexyne (6) & 1-Phenyldecane & $10 \mathrm{~b}$ & $7 \mathrm{~b}[\mathrm{e}]$ & \\
\hline $\begin{array}{l}-70 \\
-70 \\
-70 \\
\end{array}$ & $\begin{array}{l}92.6 \\
92.6 \\
92.6 \\
\end{array}$ & $\begin{array}{l}169 \\
227 \\
182\end{array}$ & $\begin{array}{l}335 \\
407 \\
370\end{array}$ & $\begin{array}{r}87 \\
134 \\
120 \\
\end{array}$ & $\begin{array}{l}0.0698 \\
0.0771 \\
0.0696 \\
\end{array}$ & $\begin{array}{l}0.100 \\
0.0896 \\
0.0979 \\
\end{array}$ & $\begin{array}{l}1.29 \\
1.44 \\
1.36 \\
\end{array}$ \\
\hline
\end{tabular}

[a] Because of the greater molar absorption coefficient of the alkyne adducts, the nucleophile ratios have been selected in a way to give comparable peak areas for the various products. - ${ }^{[b]}$ Separation on RP 18 phase with acetonitrile/water/methanol (20:20:60); retention times: $8 \mathrm{a}(16.3 \mathrm{~min}),(E)-3 \mathrm{a}(18.5 \mathrm{~min}),(Z)-3 \mathrm{a}(20.7 \mathrm{~min})$; detection at $254 \mathrm{~nm}$. - [c] Separation on RP 18 phase with acetonitrile/water/methanol (20:15:65); retention times: $8 \mathrm{~b}(34.8 \mathrm{~min}),(E)-3 \mathrm{~b}(40.3 \mathrm{~min}),(Z)-3 \mathrm{~b}(45.3 \mathrm{~min})$; detection at $254 \mathrm{~nm}$. $-[\mathrm{d}]$ Separation on $\mathrm{NO}_{2}$ phase with isooctane; retention times: $5 \mathrm{~b}(6.0 \mathrm{~min}), 9 \mathrm{~b}(7.4 \mathrm{~min})$; detection at $266 \mathrm{~nm}$. - le] Separation on RP 18 phase with water/methanol $(7: 93)$; retention times: $10 \mathrm{~b}(5.6 \mathrm{~min}), 7 \mathrm{~b}(8.6 \mathrm{~min})$; detection at $258 \mathrm{~nm}$.

were combined with $\mathrm{ZnCl}_{2}\left(\mathrm{OEt}_{2}\right)_{1.6}(1 \mathrm{mmol})$ in $25 \mathrm{ml}$ of $\mathrm{CH}_{2} \mathrm{Cl}_{2}$ for $15 \mathrm{~h}$ at $-70^{\circ} \mathrm{C}$. Workup as described above gave $650 \mathrm{mg}(71 \%)$ of colorless crystals of $10 \mathrm{~b}$ with m.p. $45-46^{\circ} \mathrm{C}$. - ${ }^{1} \mathrm{H}$ NMR $\left(\mathrm{CDCl}_{3}, 200 \mathrm{MHz}\right): \delta=1.85(\mathrm{~s}, 3 \mathrm{H}, 4-\mathrm{H}), 2.29$ (s, 6H, aryl- $\left.\mathrm{CH}_{3}\right)$, $3.11(\mathrm{~d}, J=6.4 \mathrm{~Hz}, 2 \mathrm{H}, 2-\mathrm{H}), 4.36(\mathrm{t}, J=6.4 \mathrm{~Hz}, 1 \mathrm{H}, 1-\mathrm{H})$, 7.07-7.26 (m, 8 H, aryl-H). $-{ }^{13} \mathrm{C} \mathrm{NMR}\left(\mathrm{CDCl}_{3}\right): \delta=20.9$ (q), 37.7 (q), 48.2 (d), 55.1 (t), 90.8 (s), 127.5 (d), 129.3 (d), 135.9 (s), 141.4 (s). - IR (KBr): $\tilde{v}=3010 \mathrm{~cm}^{-1}, 2857,1648,1509,1436$, $1379,1170,1066,1031,857,811,771,679,601,564$. - MS (70 $\mathrm{eV}), \mathrm{m} / \mathrm{z}(\%): 308,306(7,9)\left[\mathrm{M}^{+}\right], 195$ (100), 165 (12). $\mathrm{C}_{18} \mathrm{H}_{20} \mathrm{Cl}_{2}$ : calcd. 306.0942; found 306.0934 (MS).

Determinations of absolute rate constants were carried out at the workingstation described previously ${ }^{[7]}$ by using the concentrations listed in Table 3.

Competition Experiments: The diarylchloromethane 1a or $1 \mathrm{~b}$ (0.3-0.4 mmol) and a pair of nucleophiles (alkene or alkyne each $>2$ equivalents) were dissolved in dry $\mathrm{CH}_{2} \mathrm{Cl}_{2}(20 \mathrm{ml})$, and the solution was placed in a cryostat. After thermal equilibration, $\mathrm{ZnCl}_{2}\left(\mathrm{Et}_{2} \mathrm{O}\right)_{1.6}(0.06-0.08 \mathrm{mmol})$ was added, and the mixture was kept at the temperature given in Table 4 until $1 \mathrm{a}$ or $1 \mathrm{~b}$ had been consumed. The solution was washed with conc. aqueous ammonia $(40 \mathrm{ml})$ to destroy the catalyst, then the standard was added and the solution subsequently dried with $\mathrm{MgSO}_{4}$. After partial evaporation of the solvent, the mixture was analyzed by HPLC using the conditions given in the footnotes of Table 4.

[1] T. W. G. Solomons, Organic Chemistry, Wiley, New York, 1992, p 372.

[2] K. Yates, G. H. Schmid, T. W. Regulski, D. G. Garratt, H.-W. Leung, R. McDonald, J. Am. Chem. Soc. 1973, 95, 160.

[3] G. Modena, F. Rivetti, G. Scorrano, U. Tonellato, J. Am. Chem. Soc. 1977, 99, 3392.

[4] F. Marcuzzi, G. Melloni, G. Modena, J. Org. Chem. 1979, 44, 3022.

[5] G. Melloni, G. Modena, U. Tonellato, Acc. Chem. Res. 1981, 14, 227.

[6] R. Schneider, U. Grabis, H. Mayr, Angew. Chem. 1986, 98, 94-95; Angew. Chem. Int. Ed. Engl. 1986, 25, 89-90.

[7] H. Mayr, R. Schneider, C. Schade, J. Bartl, R. Bederke, J. Am. Chem. Soc. 1990, 112, 4446-4454.

[8] H. Mayr, R. Schneider, B. Irrgang, C. Schade, J. Am. Chem. Soc. $1990,112,4454-4459$.

[9] H. Mayr, R. Schneider, U. Grabis, J. Am. Chem. Soc. 1990, $112,4460-4467$. 
${ }^{[10]}$ H. Mayr, Angew. Chem. 1990, 102, 1415-1428; Angew. Chem. Int. Ed. Engl. 1990, 29, 1371-1384.

[11] H. Mayr, G. Hagen, J. Chem. Soc., Chem. Commun. 1989, $91-92$.

[12] G. Hagen, H. Mayr, J. Am. Chem. Soc. 1991, 113, 4954-4961.

[13] J. Bartl, S. Steenken, H. Mayr, J. Am. Chem. Soc. 1991, 113, $7710-7716$.

${ }^{[14]}$ H. Mayr, J. Bartl, G. Hagen, Angew. Chem. 1992, 104, 1689-1691; Angew. Chem. Int. Ed. Engl. 1992, 31, 1613-1615.

[15] R. Maroni, G. Melloni, G. Modena, J. Chem. Soc., Perkin Trans. 1, 1973, 2491.

${ }^{[16]}$ H. Mayr, W. Striepe, J. Org. Chem. 1983, 48, 1159-1165.
${ }^{[17]}$ R. Pock, H. Mayr, Chem. Ber. 1986, 119, 2497-2509.

${ }^{\left[{ }^{18]}\right.}$ M. Patz, H. Mayr, Tetrahedron Lett. 1993, 34, 3393-3396.

[19] R. Huisgen, Methoden Org. Chem. (Houben Weyl) 4th Ed., Bd. 3/1, Thieme Stuttgart, 1955, 144.

[20] C. K. Ingold, F. R. Shaw, J. Chem. Soc. 1949, 575-581.

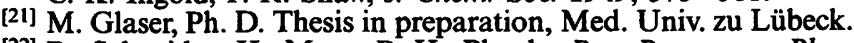

[22] R. Schneider, H. Mayr, P. H. Plesch, Ber. Bunsenges. Phys. Chem. 1987, 91, 1369-1374.

${ }^{[23]}$ H. Mayr, W. Striepe, J. Org. Chem. 1985, 50, 2995-2998.

${ }^{[24]}$ R. Pock, H. Mayr, M. Rubow, E. Wilhelm, J. Am. Chem. Soc. 1986, 108, 7767-7772.

[259/93] 